\title{
A NOTE ON THE SEX RATIO IN ANENCEPHALUS
}

\author{
BY \\ BRIAN MACMAHON* and THOMAS MCKEOWN \\ From the Department of Social Medicine, University of Birmingham
}

While exploring the association of the sex ratio of stillbirths with cause and duration of gestation, McKeown and Lowe (1951) noted that for anencephalus sex ratio increased with duration of gestation. No explanation was offered for this observation, which is here considered briefly.

In Birmingham, during the years 1940-51, 454 stillbirths and 28 infant deaths were attributed to anencephalus (440 cases) or to anencephalus and spina bifida (42 cases). Duration of gestation was recorded in $\mathbf{4 7 5}$ (of 482 cases), for which the association of sex ratio with duration of gestation was as follows:-

\begin{tabular}{c|c|c|c|c}
\hline $\begin{array}{c}\text { Duration of Gestation } \\
\text { (weeks) }\end{array}$ & Under 33 & $33-37$ & 38 and Over & Total \\
\hline $\begin{array}{c}\text { Sex Ratio (per cent. } \\
\text { male) } . .\end{array} \quad .$. & $23 \cdot 7(139)$ & $27 \cdot 3(194)$ & $42 \cdot 3(142)$ & $30 \cdot 7(475)$ \\
\hline
\end{tabular}

In Table I the distribution of anencephalics by duration of gestation is shown to be associated with birth rank, the first born being delivered earlier than the later born. Sex ratios of anencephalics of birth ranks " 1 " and " 2 and over" are respectively $26 \cdot 3$ and $35 \cdot 2$ (difference: $8 \cdot 9 \pm 4 \cdot 2$ ), which suggests that the association of duration of gestation with birth rank may account for the association of sex ratio with duration of gestation.

TABLE I

PERCENTAGE DISTRIBUTION OF ANENCEPHALICS BY DURATION OF GESTATION AND BIRTH RANK

\begin{tabular}{|c|c|c|c|c|}
\hline \multirow{2}{*}{$\begin{array}{l}\text { Birth } \\
\text { Rank }\end{array}$} & \multicolumn{4}{|c|}{ Duration of Gestation (weeks) } \\
\hline & Under 33 & $33-37$ & 38 and over & Total \\
\hline $\begin{array}{c}1 \\
2 \\
3 \\
4 \text { and over }\end{array}$ & $\begin{array}{ll}38 \cdot 3 & (93) \\
22 \cdot 8 & (23) \\
19.6 & (9) \\
16.9 & (14)\end{array}$ & $\begin{array}{ll}41 \cdot 1 & (100) \\
42 \cdot 6 & (43) \\
34 \cdot 8 & (16) \\
41 \cdot 0 & (34)\end{array}$ & $\begin{array}{ll}20 \cdot 6 & (50) \\
34 \cdot 6 & (35) \\
45 \cdot 6 & (21) \\
42 \cdot 1 & (35)\end{array}$ & $\begin{array}{l}100 \cdot 0(243) \\
100 \cdot 0(101) \\
100 \cdot 0(46) \\
100 \cdot 0(83)\end{array}$ \\
\hline Total & $29 \cdot 4$ (139) & $40 \cdot 8(193)$ & $29 \cdot 8(141)$ & $100 \cdot 0(473)$ \\
\hline
\end{tabular}

In two cases (of 475) birth rank was unknown.

$\chi^{2}=30 \cdot 34, n=6, p<0 \cdot 01$

In Table II it is shown that this explanation is unsatisfactory, since sex ratios increase with gestation for births of the same rank.

\footnotetext{
* In receipt of a grant from the Medical Research Council.
}

TABLE II

SEX RATIO OF ANENCEPHALUS RELATED TO DURATION OF GESTATION AND BIRTH RANK

\begin{tabular}{|c|c|c|c|c|}
\hline \multirow{2}{*}{$\begin{array}{l}\text { Birth } \\
\text { Rank }\end{array}$} & \multicolumn{4}{|c|}{ Duration of Gestation (weeks) } \\
\hline & Under 33 & 33-37 & 38 and over & Total \\
\hline $\begin{array}{c}1 \\
2 \\
3 \text { and over }\end{array}$ & $\begin{array}{l}22 \cdot 6(93) \\
26 \cdot 1(23) \\
26 \cdot 1(23)\end{array}$ & $\begin{array}{ll}26 \cdot 0 & (100) \\
30 \cdot 2 & (43) \\
26 \cdot 0 & (50)\end{array}$ & $\begin{array}{l}34.0(50) \\
51.4(35) \\
44.6(56)\end{array}$ & $\begin{array}{l}26 \cdot 3(243) \\
36 \cdot 6(101) \\
34 \cdot 1(129)\end{array}$ \\
\hline
\end{tabular}

In seeking for a further explanation of the observations we have considered the association of the malformation with hydramnios, a common complication which results in early onset of labour (Table III). Birth records were traced for 262 of the 319 cases born in hospital; hydramnios was noted in 182 cases, but there was no information about the degree.

TABLE III

DISTRIBUTION BY DURATION OF GESTATION OF ANENCEPHALUS WITH AND WITHOUT HYDRAMNIOS

\begin{tabular}{l|c|c|c|c}
\hline \multirow{2}{*}{ Hydramnios } & \multicolumn{3}{|c|}{ Duration of Gestation (weeks) } \\
\cline { 2 - 5 } & Under 33 & $33-37$ & 38 and over & Total \\
\hline Present & $32 \cdot 4(59)$ & $51 \cdot 1(93)$ & $16 \cdot 5(30)$ & $100 \cdot 0(182)$ \\
Absent & $27 \cdot 5(22)$ & $27 \cdot 5(22)$ & $45 \cdot 0(36)$ & $100 \cdot 0(80)$ \\
\hline Total & $30 \cdot 9(81)$ & $43 \cdot 9(115)$ & $25 \cdot 2(66)$ & $100 \cdot 0(262)$ \\
\hline & & \\
\hline
\end{tabular}

Table IV shows that the increase in sex ratio with duration of gestation is confined to cases in which hydramnios is present; in cases without hydramnios the sex ratio appears to decrease as gestation increases. The fact that the sex ratios of cases with and without hydramnios (29.7 and 32.5 respectively) are approximately the same suggests that the association between sex ratio and

TABLE IV

SEX RATIO OF ANENCEPHALUS WITH AND WITHOUT HYDRAMNIOS

\begin{tabular}{l|c|c|c|c}
\hline \multirow{2}{*}{ Hydramnios } & \multicolumn{3}{|c|}{ Duration of Gestation (weeks) } \\
\cline { 2 - 3 } & Under 33 & $33-37$ & 38 and over & Total \\
\hline $\begin{array}{l}\text { Present }(a) \\
\text { Absent }(b)\end{array}$ & $22 \cdot 0(59)$ & $26 \cdot 9(93)$ & $53 \cdot 3(30)$ & $29 \cdot 7(182)$ \\
\hline $\begin{array}{l}\text { Difference } \\
(a)-(b)\end{array}$ & $-23 \cdot 5 \pm 11 \cdot 3$ & $-0 \cdot 4 \pm 10 \cdot 5$ & $+25 \cdot 5 \pm 12 \cdot 1$ & $-2 \cdot 8 \pm 6 \cdot 2$ \\
\hline
\end{tabular}


length of gestation is not explained by a higher incidence of hydramnios in females than in males. If hydramnios is directly responsible for the earlier onset of labour in females it presumably appears earlier or is of greater severity than in males.

No explanation is offered for (a) early onset of labour in first births, which is observed in the absence of hydramnios; $(b)$ the lower sex ratio of first than of later births. These two observations appear to be independent of one another.

\section{SUMMARY}

(1) Records of 475 cases of anencephalus (454 stillbirths; 28 infant deaths) are used to investigate the increase previously reported in sex ratio with duration of gestation.
(2) It is noted that first born anencephalics are delivered earlier than later born, and that sex ratio is lower for first than for later births. These observations do not, however, account for the association of sex ratio with duration of gestation which remains when examination is confined to anencephalics of the same birth rank.

(3) It is shown that the earlier delivery of female than of male anencephalics is associated with the presence of hydramnios. Females with hydramnios are delivered earlier than affected males, although the incidence of this complication is about the same in the two sexes.

\section{REFERENCE}

McKeown, T., and Lowe, C. R. (1951). Hum. Biol., 23, 41. 